\title{
Association between animal welfare indicators and microbiological quality of beef carcasses, including Salmonella spp., from a slaughterhouse in Ecuador
}

\author{
María Cevallos-Almeida1 (iD), Ana Burgos-Mayorga² (D), Carlos A. Gómez¹D, José Luis Lema-Hurtado ${ }^{1}$ (D), \\ Leydi Lema1 ${ }^{(\mathbb{D}}$, Iveth Calvache ${ }^{1}$, Christian Jaramillo ${ }^{1}$ (iD, Isabel Collaguazo Ruilova ${ }^{1}$, \\ Evelyn Pamela Martínez² ${ }^{(\mathbb{D})}$ and Pamela Estupiñán² (i)
}

1. Laboratorio de Bacteriología y Micología, Facultad de Medicina Veterinaria y Zootecnia, Universidad Central del Ecuador, Quito, Ecuador; 2. Facultad de Medicina Veterinaria y Zootecnia, Universidad Central del Ecuador, Quito, Ecuador.

Corresponding author: María Cevallos-Almeida, e-mail: bcevallos@uce.edu.ec

Co-authors: AB: arburgos@uce.edu.ec, CAG: cgomez@uce.edu.ec, JLL: jllemah@uce.edu.ec, LL: Iylema@uce.edu.ec, IC: iacalvache@uce.edu.ec, CJ: cajaramillop@uce.edu.ec, ICR: ricollaguazo@uce.edu.ec, EPM: pmartinezl@uce.edu.ec, PE: ptestupinan@uce.edu.ec

Received: 09-11-2020, Accepted: 01-03-2021, Published online: 16-04-2021

doi: www.doi.org/10.14202/vetworld.2021.918-925 How to cite this article: Cevallos-Almeida M, Burgos-Mayorga $A$, Gómez CA, Lema-Hurtado JL, Lema L, Calvache I, Jaramillo C, Collaguazo Ruilova I, Martínez EP, Estupiñán P (2021) Association between animal welfare indicators and microbiological quality of beef carcasses, including Salmonella spp., from a slaughterhouse in Ecuador, Veterinary World, 14(4): 918-925.

\begin{abstract}
Background and Aim: Pre-slaughter management and slaughter operations are considered critical factors for animal welfare and meat quality. Previous studies have found poor animal welfare management at municipal slaughterhouses in Ecuador, and little is known about how this affects the microbiological quality of the meat. Therefore, the aim of the study was to analyze the association of the microbiological quality of beef carcasses and animal welfare indicators in a municipal slaughterhouse in Ecuador.

Materials and Methods: Data for 6 months were collected from a municipal slaughterhouse in Ecuador. Five trained researchers were strategically located along the slaughter process. A total of 351 animals were observed with regard to welfare indicators, and their carcasses were sampled to evaluate microbiological quality. Antemortem (slipping, falling, and vocalization) and postmortem animal welfare indicators (bleed interval, $\mathrm{pH}$, temperature, and bruises) were measured. To determine the total aerobic bacteria (TAB) and Escherichia coli counts and the presence of Salmonella spp., we collected samples by swabbing four different points of each carcass. The association between microbiological quality and animal welfare indicators was studied using univariate and multivariate logistic regressions.
\end{abstract}

Results: The mean TAB count was $5.3 \log \mathrm{CFU} / \mathrm{cm}^{2}$, and the mean total count of E. coli was $2.4 \log \mathrm{CFU} / \mathrm{cm}^{2}$. Salmonella spp. were isolated in $3.1 \%$ of the carcasses. An electric goad was used in all animals, $19.1 \%$ slipped at least once, and $19.9 \%$ vocalized. The mean $\mathrm{pH}$ of the carcasses was 7.2 , and $79.2 \%$ of carcasses had bruises. Multivariate analysis showed that Salmonella spp. and the TAB count were associated with $\mathrm{pH}$ and the number of bruises ( $\mathrm{p}=0.01$ in both cases).

Conclusion: Although there was non-significant association between the majority of animal welfare indicators and microbiological quality, the poor management affecting animal welfare and carcass hygiene are worrisome.

Keywords: animal welfare, beef carcasses, Escherichia coli, Salmonella spp., total aerobic bacteria.

\section{Introduction}

Beef production is an important global economic activity, especially in developing countries. In Latin America and the Caribbean, livestock is considered the basic protein source for food security, and the consumption of animal-sourced proteins is considered the most important strategy to bolster the health of local populations [1]. In Ecuador, the cattle population is approximately 4.13 million heads, located mainly in rural areas [2], and $84 \%$ of rural households own

Copyright: Cevallos-Almeida, et al. Open Access. This article is distributed under the terms of the Creative Commons Attribution 4.0 International License (http://creativecommons.org/licenses/ by/4.0/), which permits unrestricted use, distribution, and reproduction in any medium, provided you give appropriate credit to the original author(s) and the source, provide a link to the Creative Commons license, and indicate if changes were made. The Creative Commons Public Domain Dedication waiver (http:// creativecommons.org/publicdomain/zero/1.0/) applies to the data made available in this article, unless otherwise stated. livestock, with an average of 2.8 heads per household [1]. In 2016, Ecuadorians were estimated to have consumed 182,000 tons/year of beef, with $17.6 \mathrm{~kg}$ of beef per person per year [3].

Pre-slaughter and slaughter operations are considered the most important critical factors for meat quality and food security [4]. Pre-slaughter factors, such as failures in handling practices during loading and unloading and during transport, unskilled drivers, long-distance travel, high density during transport, and inadequate lairage facilities at the slaughterhouse (e.g., privation of water), can induce stress in animals and decrease animal welfare [5-7]. Stress, in turn, can induce metabolic and hormonal alterations, leading to changes in the color, $\mathrm{pH}$, and water-holding capacity of the meat [8]. In addition, bad slaughter management during unclean (e.g., stunning and bleeding) and clean (e.g., evisceration and carcass splitting) operations 
can affect the carcass quality due to cross-contamination [9]. Post-slaughter factors, such as temperature, humidity, and storage time, also affect the final microbiological quality of the meat [10].

In many countries, the identification of microorganisms such as Salmonella spp., the total aerobic bacteria (TAB) count, and the Escherichia coli count are used as criteria for assessing good slaughter hygiene in beef [11]. Therefore, microbiological data are essential to implement meat-quality-monitoring programs to prevent the transmission of common foodborne diseases [12]. In Ecuador, most slaughterhouses are public and operated by municipalities providing slaughter service at subsidized rates to wholesalers. Service quality is low with regard to animal welfare and humane handling practices [13]. The demand for high-quality beef is increasing, and consumers are willing to pay more for products obtained with better animal welfare and sanitary control [13]. However, previous studies have found poor animal welfare management at municipal slaughterhouses in Ecuador [14-17], and little is known about how this affects the microbiological quality of the meat.

Therefore, this study determined the association between animal welfare indicators and the microbiological quality of beef carcasses from a municipal slaughterhouse in Ecuador.

\section{Materials and Methods}

\section{Ethical approval}

Ethical approval was not necessary for this study since it merely focused on observing the animal welfare management performed at the slaughterhouse, and no questionnaire survey was performed. However, the skin painted used on selected animals was done without any harm, and the microbiological samples were collected according to standardized methods.

\section{Study design, period, location, and sampling}

This cross-sectional study was conducted from November 2018 to April 2019 in a slaughterhouse in Ecuador. The slaughterhouse provides slaughter service to wholesalers coming from the coast, highlands, and Amazon regions of Ecuador. On an average, 500 animals are slaughtered every day. On the basis of this number, we calculated a desired total sample size of 351 animals at a $95 \%$ confidence interval (CI). To ensure correct observation of animal welfare indicators and considering the time constraints for bacterial isolation, we randomly selected an average of 25 animals from pens 1 day/week (only Mondays).

Five researchers were strategically located along the slaughter process, from pens to the final point in the slaughter line commercial area. For sampling, the researchers talked to each other using walkie-talkies to follow individual carcasses. Each selected animal was assigned a number, which was drawn on the animal's skin on both the head and the flank with blue paint. Once the skin was removed at the first point of the slaughter line, the carcass was identified with a livestock tag ring with the same number. The tag ring was attached around the animal's Achilles tendon, which was removed after sampling. This procedure has been used in previous studies in the same slaughterhouse and was found to be useful to follow animals and carcasses. Workers at the slaughterhouse saw these marks during every trial, but they kept doing their job as usual $[15,17]$.

\section{Assessment of animal welfare}

We evaluated antemortem and postmortem animal welfare indicators using the recommendations of the North American Meat Institute (NAMI) and the World Organization for Animal Health [18,19]. Antemortem indicators were observed directly and included the number of times an animal slipped and fell, the number of vocalizations, and the use of an electric goad (yes/ no). Slipping, falling, and vocalizations were counted during animal handling from the holding pen to the stunning box. Falling was counted as loss of contact of all four legs with the floor or the belly of the animal touching the floor. Slipping was counted as any loss of footing. Vocalizations were measured only when they occurred due to the electric goad, hits by handlers, or other abusive actions, such as holding the animals by the horns. The use of an electric goad was counted when electric discharge was effectively done [18].

Postmortem indicators were measured after stunning and included the number of shots needed for stunning, the stunning-to-bleed interval, $\mathrm{pH}$, temperature, and the number of bruises. The stunningto-bleed interval was defined as the time from effectively stunning (i.e., unconsciousness) the animal to cut the blood vessels in the neck and upper chest and was measured in seconds. To evaluate the return to consciousness, we observed the animal's eye reflexes (e.g., corneal reflexes and mydriasis), reaction to pain, rhythmic breathing, and vocalizations [18]. Any tissue lesion with a decoloring zone due to the rupture of blood capillaries was considered a bruise [20]. Bruises were counted in four regions: (1) The front, from the neck to the front leg; (2) the back, the muscles around the spine from the shoulders to the lumbar region; (3) the ribs, the muscles in the flanks; and (4) the rump and rear legs. The $\mathrm{pH}$ and temperature were measured 45 min after stunning, using a portable potentiometer (Hannah Instruments,USA) with a penetration electrode in the Longissimus dorsi muscle. The latter procedure was in accordance with the Ecuadorian standard INEN-ISO 2917:2013 [21].

\section{Isolation and bacterial identification}

Microbiological analyses were performed in the Laboratory of Bacteriology at the Faculty of Veterinary Medicine and Zootechnics, Central University of Ecuador. Carcasses marked with livestock tag rings were sampled for microbiological quality at the end of the slaughter line after washing.

Samples were collected using a nondestructive swab method with a sponge soaked in buffered 
peptone water [22]. Samples were taken at four points identified as highly contaminated areas: Hip, skirt, chest, and neck [23]. The sampling area was $100 \mathrm{~cm}^{2}$, defined by a sterile plastic frame. Subsequently, the sponge was placed in a Ziploc bag and kept at $4^{\circ} \mathrm{C}$ [22]. Next, the samples were diluted $(1: 10)$ in buffered peptone water (Difco, USA) and then serially diluted in $0.45 \%$ saline solution until a dilution of $10^{-3}$ was obtained. Then, $100 \mu \mathrm{L}$ of dilutions $10^{-2}$ and $10^{-3}$ was plated on Chromocult Agar (Merck, USA) for the E. coli count and Plate Count Agar (BD-Difco, USA) for the TAB count $\left(\mathrm{CFU} / \mathrm{cm}^{2}\right)$; the estimation was done according to the ISO 7218 standard [24].

Salmonella spp. isolation was done according to the ISO 6579 standard [25]. Briefly, three drops of the initial suspension were dispensed on Modified Semi-Solid Rappaport Vassiliadis (BD-Difco) and incubated at $42^{\circ} \mathrm{C}$ for $24-48 \mathrm{~h}$. Presumptive colonies were observed and classified according to their growth and migration $(\mathrm{CM})$, growth without migration $(\mathrm{CNM})$, and non-growth (NC). A loopful from the edge of the migration zone was streaked into a xylose lysine deoxycholate agar plate (BD-Difco) and incubated at $37^{\circ} \mathrm{C}$ for $24 \mathrm{~h}$. For confirmation, two presumptive Salmonella spp. colonies were tested using Triple Sugar Iron agar (BD-Difco), Lysine Iron agar (BD-Difco), Urea agar (BD-Difco), and Sulfur Indole Motility medium (BD-Difco) [26].

\section{Statistical analysis}

Statistical analyses were performed using R Cran 3.6.1 and R Studio version 1.1.442 (R Foundation for Statistical Computing, Vienna, Austria, URL https:// www.R-project.org/). TAB and E. coli counts were

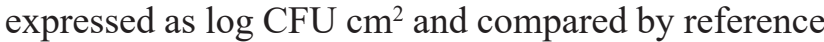
to mean values. Salmonella spp. were expressed as their absence and presence. Reference values for animal welfare indicators were based on NAMI and Food and Agriculture Organization guidelines and similar studies [18,27-29]. Reference values for microbiological quality parameters were based on European Union guidelines and the Food Security Criteria from Argentina [30,31].

Visual inspections of histograms showed a clear binomial distribution of TAB and E. coli counts. Therefore, these variables were categorized for further analysis as below and above reference values. The above category for the TAB count was applied for counts more than $5.0 \log \mathrm{CFU} / \mathrm{cm}^{2}$ and for $E$. coli counts more than $2.5 \log \mathrm{CFU} / \mathrm{cm}^{2}$.

To explore the association of microbiological parameters with welfare indicators, logistic regression models were applied to calculate crude and adjusted odd ratios (ORs) and their 95\% CIs. Univariate analysis was used to identify potential explanatory variables to be included in multivariate analysis. Models were fitted separately with the TAB, E. coli, and Salmonella spp. as binary outcome variables. The following explanatory variables were considered: Falling (yes/ no, counts), slipping (yes/no, counts), vocalizations (yes/no, counts), bruises (yes/no, counts), temperature, and $\mathrm{pH}$.

Multivariate models were built using forward stepwise selection, and the model with the lowest Akaike information criterion (AIC) was considered the best. The AIC has been widely used to evaluate the goodness of fit [32]. Variables that were not statistically significant and did not improve the AIC were excluded from the models.

\section{Results}

\section{Microbiological quality and animal welfare parameters}

Table-1 shows the parameters related to animal welfare and the microbiological quality of the carcasses. Aerobic bacteria were isolated in $100 \%$ of the carcasses, and E. coli and Salmonella spp. were isolated in $34.5 \%(121 / 351)$ and $3.1 \%(11 / 351)$ of the carcasses, respectively. The TAB count was 4.1-6.43 $\log \mathrm{CFU} / \mathrm{cm}^{2}$, and $81.8 \%(287 / 351)$ of the samples were above the reference limit of $5 \log \mathrm{CFU} / \mathrm{cm}^{2}$. The E. coli count was $0-5.4 \log \mathrm{CFU} / \mathrm{cm}^{2}$, and $65.5 \%$ (230/351) of the samples were above the reference limit of $2.5 \log \mathrm{CFU} / \mathrm{cm}^{2}$. With regard to antemortem indicators, $7.7 \%(25 / 351)$ of the animals fell and $19.08 \%(67 / 351)$ slipped on the way to the stunning box. An electric goad was used in all observed animals, with a mean of $5.2 \pm 4.2$. In addition, $19.9 \%$ (70/351) of the animals vocalized due to human handling, with a mean of $0.7 \pm 3.4$ vocalizations per animal. The mean stunning-to-bleed interval was $135.8 \pm 107.2 \mathrm{~s}$.

With regard to postmortem indicators, we found bruises in $79.2 \%(278 / 351)$ of the carcasses, with a mean of $2.5 \pm 2.2$ per carcass. The majority of bruises were located on the rump (78.8\%) and were subcutaneous $(65.1 \%)$. The mean $\mathrm{pH}$ was 7.2 , with $46.1 \%$ $(166 / 351)$ of the carcasses having $\mathrm{pH}$ values of $>7.3$. The mean temperature in the sampled carcasses kept in the commercial area was $29.9^{\circ} \mathrm{C}$ (Table-1).

\section{Association between animal welfare indicators and microbiological quality of carcasses}

Tables- 2 and 3 show the ORs for high TAB and E. coli counts and the presence of Salmonella spp. Most of the antemortem and postmortem animal welfare indicators were not associated with high TAB and E. coli counts and the presence of Salmonella spp. in beef carcasses. Interestingly, univariate analysis revealed that the increase in $\mathrm{pH}$ significantly decreased the odds for high $\mathrm{TAB}$ counts $(\mathrm{OR}=0.34$, $95 \% \mathrm{CI}=0.13-0.80, \mathrm{p}=0.02)$ and the presence of Salmonella spp. $\quad(\mathrm{OR}=0.08, \quad 95 \% \quad \mathrm{CI}=0.02-0.43$, $\mathrm{p}=0.003)$ (Table-2). This effect was still significant when adjusting for slipping and vocalizations for the TAB count $(\mathrm{OR}=0.28,95 \% \mathrm{CI}=0.11-0.70, \mathrm{p}=0.01)$ and the number of bruises for Salmonella $\mathrm{spp}$. ( $\mathrm{OR}=0.10$, 95\% CI $=0.02-0.51, \mathrm{p}=0.01$ ) (Table-3).

In addition, the presence of Salmonella spp. was significantly lower with the presence of bruises 
Table-1: Summary data of parameters regarding microbiological quality in beef carcasses and animal welfare indicators.

\begin{tabular}{|c|c|c|c|c|c|}
\hline \multirow[t]{2}{*}{ Parameters } & \multirow[t]{2}{*}{ n (\%) } & \multirow[t]{2}{*}{ Mean (SD) } & \multirow[t]{2}{*}{ Range } & \multirow[t]{2}{*}{ Reference values ${ }^{a}$} & \multirow{2}{*}{$\frac{\text { Above reference }}{\mathrm{n}(\%)}$} \\
\hline & & & & & \\
\hline \multicolumn{6}{|l|}{ Microbiological quality } \\
\hline TAB (log UFC/ $\left.\mathrm{cm}^{2}\right)$ & $351(100.0)$ & $5.32(0.39)$ & $4.1-6.4$ & $3.5-5.0$ & $287(81.8)$ \\
\hline E. coli $\left(\mathrm{log} \mathrm{UFC} / \mathrm{cm}^{2}\right)$ & $121(34.4)$ & $2.4(1.8)$ & $0.0-5.4$ & $0.7-2.5$ & $230(65.5)$ \\
\hline Salmonella spp. & $11(3.1)$ & - & - & Absence & $11(3.1)$ \\
\hline \multirow{2}{*}{\multicolumn{6}{|c|}{$\begin{array}{l}\text { Animal welfare indicators } \\
\text { Antemortem }\end{array}$}} \\
\hline & & & & & \\
\hline Falling & $25(7.1)$ & $0.1(0.3)$ & $0.0-1.0$ & $<1 \%$ & $25(7.1)$ \\
\hline Slipping & $67(19.1)$ & $0.27(0.7)$ & $0.0-5.0$ & $<3 \%$ & $67(19.1)$ \\
\hline Vocalizations & $70(19.9)$ & $0.7(3.4)$ & $0.0-49.0$ & $<3 \%$ & $70(19.9)$ \\
\hline Electric prod usage & $351(100.0)$ & $5.2(4.2)$ & $1.0-32.0$ & $<25 \%$ & $351(100.0)$ \\
\hline \multicolumn{6}{|l|}{ Postmortem } \\
\hline Bruising & $278(79.2)$ & $2.5(2.2)$ & $0.0-9.0$ & NA & NA \\
\hline Front & $24(8.6)$ & - & - & - & - \\
\hline Back & $7(2.5)$ & - & - & - & - \\
\hline Ribs & $28(10.1)$ & - & - & - & - \\
\hline Rump & $219(78.8)$ & - & - & - & - \\
\hline Subcutaneous & $181(65.1)$ & - & - & - & - \\
\hline Muscle & $97(34.9)$ & - & - & - & - \\
\hline S/B interval (s) & - & $135.8(107.2)$ & $31.0-1282.0$ & $<60 \mathrm{~s}$ & $300(85.5)$ \\
\hline $\mathrm{pH}_{45}$ & - & $7.2(0.3)$ & $5.8-8.0$ & $<7$ & $237(67.5)$ \\
\hline Temperature $\left({ }^{\circ} \mathrm{C}\right)$ & - & $29.9(1.3)$ & $25.0-34.1$ & $<35^{\circ} \mathrm{C}$ & $0(0.0)$ \\
\hline
\end{tabular}

$\mathrm{NA}=$ Not applicable, S/B interval, stunning bleed interval measured in seconds; $\mathrm{pH}_{45} \mathrm{pH}$ measured $45 \mathrm{~h}$ after slaughter. aReference values for microbiological quality were based on a combination of regulations from the European Union and Argentina, and for animal welfare indicators were mainly based on the NAMI and FAO guidelines. Reference values for antemortem animals welfare indicators refer to the maximum percentage of animals over the total observed animals. There is no reference value for number of bruises. E. coli=Escherichia coli, TAB=Total aerobic bacteria

$(\mathrm{OR}=0.20,95 \% \mathrm{CI}=0.06-0.70, \mathrm{p}=0.01)$ and when the carcasses had one to four bruises $(\mathrm{OR}=0.11,95 \%$ $\mathrm{CI}=0.02-0.52, \mathrm{p}=0.01)$. However, the number of vocalizations was weakly associated with the presence of Salmonella spp. (OR=1.09, 95\% CI=1.01-1.20, $\mathrm{p}=0.02$ ), but this effect disappeared when included in the multivariate model (Table-3). We did not find a significant effect of animal welfare indicators on $E$. coli presence. However, the odds for having the E. coli count increased by $\sim 20-30 \%$ when the animal fell and the carcasses had bruises (Table-2).

\section{Discussion}

This study analyzed the microbiological quality of beef carcasses, including the TAB count, the E. coli count, and the presence of Salmonella spp., and its association with animal antemortem (vocalization, slipping, falling, and use of an electric prod) and postmortem (bruises, stunning/bleed interval, $\mathrm{pH}$, and temperature) animal welfare indicators in a municipal slaughterhouse in Ecuador. The majority of animal welfare indicators were not associated with microbiological quality. However, there was evidently poor welfare management.

A higher $\mathrm{pH}$ reduced the risk of the presence of Salmonella spp. and a TAB count of $>5.0 \log$ CFU/ $\mathrm{cm}^{2}$. Probably, this result is an effect of the measurement of $\mathrm{pH} 45$ min after stunning, resulting in a mean of 7.1. According to NAMI guidelines, the measurement of postmortem indicators, such as $\mathrm{pH}$, temperature, and bruises, should be done $24 \mathrm{~h}$ after slaughter [18]. However, the slaughterhouse in this study only provides slaughter service, and beef carcasses are dispatched to wholesalers immediately after slaughter. Therefore, postmortem indicators were measured just before dispatch. The $\mathrm{pH}$, water activity, and temperature of carcasses are factors that affect microbial growth and survival. In fact, $\mathrm{pH}$ values of $>9$ or $<4$ can inhibit Salmonella spp. growth [31].

Our results showed that the risk of the presence of Salmonella spp. is low when the number of bruises is high, regardless of the fact that $79.2 \%$ of the carcasses had at least one bruise. The presence of bruises has been widely used as an indicator of animal welfare [33-35]. Its presence is associated with poor pre-slaughter handling factors related to transport, food and water privation, lairage, and stunning, which lead to physical distress and subsequent changes in meat quality [4]. For instance, food and water deprivation of 12-24 h results in a significantly higher muscle $\mathrm{pH}$ (up to 5.6, $\mathrm{p}<0.05$ ) in poultry, and it increases the number of bruises in pigs [36,37]. Although these effects are hard to see in cattle after 12-24 h [38], it is possible that both the presence of bruises and a $\mathrm{pH}$ of 7 could lower the risk of the presence of Salmonella spp. as much as it did in our study $(\mathrm{OR}=0.10, \mathrm{p}=0.01)$, in addition to TAB and E. coli counts. However, further studies are necessary to fully understand these associations by measuring $\mathrm{pH}$ and bruises after $24 \mathrm{~h}$ and including samples from bruises for microbiological analysis.

Surprisingly, we did not find a significant association between antemortem animal welfare indicators and microbiological quality, regardless of the 
Table-2: Univariate odds ratio for the presence of Aerobic Bacteria, E. coli and Salmonella spp. based on animal welfare indicators.

\begin{tabular}{|c|c|c|c|c|c|c|c|c|c|}
\hline \multirow{3}{*}{$\begin{array}{l}\text { Welfare } \\
\text { indicators }\end{array}$} & \multicolumn{3}{|c|}{ Presence of aerobic bacteria } & \multicolumn{3}{|c|}{ Presence of E. coli } & \multicolumn{3}{|c|}{ Presence of Salmonella spp. } \\
\hline & \multirow{2}{*}{ 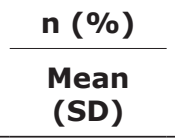 } & \multirow{2}{*}{$\begin{array}{c}\text { OR } \\
(95 \% \mathrm{CI})\end{array}$} & \multirow[t]{2}{*}{ p-value } & \multirow{2}{*}{$\begin{array}{c}\text { n (\%) } \\
\text { Mean } \\
(\text { SD) }\end{array}$} & \multirow{2}{*}{$\begin{array}{c}\text { OR } \\
(95 \% \mathrm{CI})\end{array}$} & \multirow[t]{2}{*}{ p-value } & n (\%) & \multirow{2}{*}{$\begin{array}{c}\text { OR } \\
(95 \% \mathrm{CI})\end{array}$} & \multirow[t]{2}{*}{ p-value } \\
\hline & & & & & & & $\begin{array}{l}\text { Mean } \\
(\text { SD })\end{array}$ & & \\
\hline \multicolumn{10}{|l|}{ Antemortem } \\
\hline \multicolumn{10}{|l|}{ Falling } \\
\hline No & 267 (81.9) & Ref. & & $212(65.0)$ & Ref. & & $9(2.8)$ & Ref. & \\
\hline Yes & $20(80.0)$ & $\begin{array}{c}0.88 \\
(0.31-3.14)\end{array}$ & 0.81 & $18(72.0)$ & $\begin{array}{c}1.38 \\
(0.58-3.65)\end{array}$ & 0.48 & $2(8.0)$ & $\begin{array}{c}3.06 \\
(0.45-12.78)\end{array}$ & 0.19 \\
\hline \multicolumn{10}{|l|}{ Slipping } \\
\hline No & $228(80.3)$ & Ref. & & $187(65.9)$ & Ref. & & $8(2.8)$ & Ref. & \\
\hline Yes & $5(88.6)$ & $\begin{array}{c}1.81 \\
(0.80-4.63)\end{array}$ & 0.14 & $43(64.2)$ & $\begin{array}{c}0.93 \\
(0.54-1.64)\end{array}$ & 0.80 & $3(4.5)$ & $\begin{array}{c}1.62 \\
(0.35-5.77)\end{array}$ & 0.49 \\
\hline Counts & $0.3(0.7)$ & $\begin{array}{c}1.30 \\
(0.85-2.31)\end{array}$ & 0.55 & $0.3(0.7)$ & $\begin{array}{c}1.02 \\
(0.75-1.43)\end{array}$ & 0.91 & $0.3(0.7)$ & $\begin{array}{c}1.0 \\
(0.30-1.87)\end{array}$ & 0.99 \\
\hline \multicolumn{10}{|l|}{ Vocalization } \\
\hline No & $232(82.6)$ & Ref. & & $182(64.8)$ & Ref. & & $10(3.6)$ & Ref. & \\
\hline Yes & $55(78.6)$ & $\begin{array}{c}0.74 \\
(0.41-1.52)\end{array}$ & 0.44 & $48(68.6)$ & $\begin{array}{c}1.19 \\
(0.68-2.11)\end{array}$ & 0.55 & $1(1.4)$ & $\begin{array}{c}0.39 \\
(0.02-2.10)\end{array}$ & 0.38 \\
\hline Counts & $0.7(3.4)$ & $\begin{array}{c}0.96 \\
(0.89-1.05)\end{array}$ & 0.19 & $0.7(3.4)$ & $\begin{array}{c}0.97 \\
(0.90-1.04)\end{array}$ & 0.39 & $0.7(3.4)$ & $\begin{array}{c}1.09 \\
(1.01-1.20)\end{array}$ & 0.02 \\
\hline Electric prod use & $5.2(4.2)$ & $\begin{array}{c}0.98 \\
(0.93-1.05)\end{array}$ & 0.55 & $5.2(4.2)$ & $\begin{array}{c}1.02 \\
(0.97-1.08)\end{array}$ & 0.43 & $5.2(4.2)$ & $\begin{array}{c}1.04 \\
0.90-1.15)\end{array}$ & 0.51 \\
\hline \multicolumn{10}{|l|}{ Postmortem } \\
\hline \multicolumn{10}{|l|}{ Bruises } \\
\hline No & $58(79.5)$ & Ref. & & $45(61.6)$ & Ref. & & $6(8.2)$ & Ref. & \\
\hline Yes & $229(82.3)$ & $\begin{array}{c}1.21 \\
(0.59-2.38)\end{array}$ & 0.57 & $185(66.6)$ & $\begin{array}{c}1.24 \\
(0.72-2.10)\end{array}$ & 0.43 & $5(1.8)$ & $\begin{array}{c}0.2 \\
(0.06-0.70)\end{array}$ & 0.01 \\
\hline Counts & $2.5(2.2)$ & $\begin{array}{c}0.98 \\
(0.86-1.11)\end{array}$ & 0.69 & $2.5(2.2)$ & $\begin{array}{c}0.98 \\
(0.89-1.09)\end{array}$ & 0.74 & $2.5(2.2)$ & $\begin{array}{c}0.96 \\
(0.70-1.26)\end{array}$ & 0.78 \\
\hline S/B interval (s) & $\begin{array}{c}135.8 \\
(107.2)\end{array}$ & $\begin{array}{c}1.00 \\
(1.00-1.00)\end{array}$ & 0.49 & $\begin{array}{c}135.8 \\
(107.2)\end{array}$ & $\begin{array}{c}1.00 \\
(1.00-1.00)\end{array}$ & 0.06 & $\begin{array}{c}135.8 \\
(107.2)\end{array}$ & $\begin{array}{c}1.0 \\
(0.99-1.00)\end{array}$ & 0.46 \\
\hline $\mathrm{pH}$ & $7.2(0.33)$ & $\begin{array}{c}0.34 \\
(0.13-0.80)\end{array}$ & 0.02 & $7.2(0.33)$ & $\begin{array}{c}0.53 \\
(0.26-1.05)\end{array}$ & 0.07 & $7.2(0.33)$ & $\begin{array}{c}0.08 \\
(0.02-0.43)\end{array}$ & 0.003 \\
\hline Temperature $\left({ }^{\circ} \mathrm{C}\right)$ & $29.9(1.3)$ & $\begin{array}{c}0.95 \\
(0.69-1.33)\end{array}$ & 0.78 & $29.9(1.3)$ & $\begin{array}{c}1.1 \\
(0.93-1.30)\end{array}$ & 0.27 & $29.9(1.3)$ & $\begin{array}{c}1.17 \\
(0.74-1.91)\end{array}$ & 0.52 \\
\hline
\end{tabular}

$\mathrm{OR}=$ Odds ratio, Ref., reference category, S/B interval, stunning bleed interval measured in seconds. E. coli=Escherichia coli

evidently poor management, probably because the true effect of animal welfare indicators was not captured due to a high level of carcass contamination. Indeed, $81.8 \%$ of the carcasses had a TAB count higher than the reference value of $5 \log \mathrm{CFU} / \mathrm{cm}^{2}$, and $65.5 \%$ of the carcasses had an E. coli count higher than $2.5 \log \mathrm{CFU} / \mathrm{cm}^{2}$. Although not significant, slipping could double the risk of having a high TAB count. Slipping, falling, and vocalization have been related with the high use of an electric goad [34,39] and poor infrastructure [40,41]. In this study, $100 \%$ of the observed animals were prodded toward the stunning box using an electric goad, of which $7.1 \%$ fell, $19.1 \%$ slipped, and $19.9 \%$ vocalized. Of note, none of these antemortem indicators complied with NAMI guidelines [18], reflecting the serious shortcoming of animal welfare management at the slaughterhouse. These results should be studied further to increase awareness of pre-slaughter management, which certainly could affect meat quality traits such as color, $\mathrm{pH}$, conductivity, shelf life, and water retention [8].

The mean TAB $\left(5.3 \log \mathrm{CFU} / \mathrm{cm}^{2}\right)$ and E. coli $\left(2.4 \log \mathrm{CFU} / \mathrm{cm}^{2}\right)$ counts found in this study were comparable with the previous studies. Two studies in Brazil reported a mean E. coli count of $2.11 \mathrm{log}$ $\mathrm{CFU} / \mathrm{cm}^{2}$ and $2.57 \log \mathrm{CFU} / \mathrm{cm}^{2}$, respectively, in beef carcasses $[12,42]$. A study in Europe reported a mean E. coli count of $2.5 \log \mathrm{CFU} / \mathrm{cm}^{2}$ in beef carcasses and a lower mean of $0.9 \log \mathrm{CFU} / \mathrm{cm}^{2}$ in sheep carcasses [43]. We found high variability in the E. coli count, ranging from 0.0 to $5.4 \log \mathrm{CFU} / \mathrm{cm}^{2}$, probably due to the geographical diversity of animals arriving at the slaughterhouse, their age, hygiene, and facility cleaning $[42,44]$. In contrast with our findings, TAB counts were higher than the counts reported from samples collected after bleeding cattle at a slaughter line in Brazil (4.51 log CFU/ $\left.\mathrm{cm}^{2}\right)$ [12].

In addition, $3.1 \%$ of our samples were positive for Salmonella spp. compared to five slaughterhouses in the coastal region of Ecuador where this bacterium was not isolated from 70 samples [10]. However, this percentage was low compared to other studies. In three Brazilian slaughterhouses, $6.7 \%$ of the 90 samples collected at three different points in the slaughter line (stunning, washing, and cooling) were positive for Salmonella spp. [45]. Besides, a study in Mexico isolated Salmonella spp. from $18 \%$ of the carcasses, 
Table-3: Multivariate odds ratio for the presence of aerobic bacteria (Model A) and Salmonella spp. (Model B) based on animal welfare indicators.

\begin{tabular}{|c|c|c|c|c|c|}
\hline \multirow[t]{2}{*}{ Variables } & n/n (\%) & \multirow[t]{2}{*}{ OR } & \multirow[t]{2}{*}{$95 \% \mathrm{CI}$} & \multirow[t]{2}{*}{ SE } & \multirow[t]{2}{*}{ p-value } \\
\hline & mean $( \pm S D)$ & & & & \\
\hline \multirow{2}{*}{\multicolumn{6}{|c|}{$\begin{array}{l}\text { Model A: Presence of aerobic bacteria } \\
\text { Slipping }\end{array}$}} \\
\hline & & & & & \\
\hline No & $228 / 284(80.3)$ & Ref. & & & \\
\hline Yes & $59 / 67(88.1)$ & 2.10 & $0.97-3.86$ & 0.42 & 0.08 \\
\hline \multicolumn{6}{|c|}{ Vocalizations } \\
\hline Counts & $0.73(3.4)$ & 0.94 & $0.87-1.01$ & 0.03 & 0.07 \\
\hline $\mathrm{pH}$ & $7.17(0.3)$ & 0.28 & $0.11-0.70$ & 0.47 & 0.01 \\
\hline \multicolumn{6}{|c|}{ Model B: Presence of Salmonella spp. } \\
\hline \multicolumn{6}{|l|}{ Bruises } \\
\hline 0 & $6 / 73(8.2)$ & Ref. & & & \\
\hline $1-4$ & $2 / 214(9.3)$ & 0.11 & $0.02-0.52$ & 0.84 & 0.01 \\
\hline $5-9$ & $3 / 64(4.7)$ & 0.55 & $0.11-2.30$ & 0.75 & 0.43 \\
\hline $\mathrm{pH}$ & $7.17(0.33)$ & 0.10 & $0.02-0.51$ & 0.87 & 0.01 \\
\hline
\end{tabular}

$\mathrm{OR}=$ Odds ratio, Ref., reference category. Model $\mathrm{A}$ and Model B included variables based on its significant and Akaike information criterion

$39 \%$ of beef chunks, and $71 \%$ of ground beef samples, indicating that the Salmonella spp. prevalence tends to increase with meat processing [46]. The variability in the presence of Salmonella spp. can also be explained by the size of the establishment. One study found a much higher Salmonella spp. prevalence in beef carcasses in a small-scale $(<500$ employees) slaughterhouse compared to that of our study $(58 \%$ vs. $3.2 \%$ ), possibly due to the fact that samples in that study were taken pre-evisceration, before the washing process [47]. In our study, carcasses were sampled after washing, which may have lowered the load of Salmonella spp. [48].

Our study had a few strengths but also some limitations. This is the first study covering the association of the microbiological quality of beef carcasses and animal welfare indicators in a municipal slaughterhouse in Ecuador. Although we could not find a strong association between them, the measured indicators were useful to describe the hygiene and animal welfare management in the slaughterhouse, which only provides slaughter service. One limitation was the inability to measure postmortem animal welfare indicators $24 \mathrm{~h}$ after slaughter, which made it difficult to compare our results with other studies. Nevertheless, our findings showed worrisome poor welfare and hygiene management consistent with the previous studies performed in the same slaughterhouse $[15,17]$. A high bacteria count in the first point of the slaughter line suggests higher contamination by the end of the slaughter process $[12,46,49]$. Therefore, further studies should consider using different sampling points along the slaughter line. Another limitation was the lack of information regarding animal demographic factors, transportation, and handling during lairage, since these are not routinely collected. These factors can affect the microbiological quality of meat, as shown in other studies [50,51].

\section{Conclusion}

The majority of animal welfare indicators were not associated with the microbiological quality of beef carcasses. Only $\mathrm{pH}$ and bruises are associated with a low risk of the presence of Salmonella spp. and the TAB count. More importantly, the municipal slaughterhouse in Ecuador has a worryingly low microbiological quality of beef carcasses and poor animal welfare management, indicating the necessity of further studies on these two aspects.

\section{Authors' Contributions}

$\mathrm{AB}, \mathrm{EPM}, \mathrm{PE}$, and $\mathrm{MC}$ conceived and designed the study. CAG, MC, LL, and JLL did the microbiology analysis at the laboratory. IC, ICR, and CJ, measured animal welfare indicators at the slaughterhouse. $\mathrm{EPM}$ and $\mathrm{AB}$ analyzed the data. EPM, $\mathrm{AB}, \mathrm{MC}$, and $\mathrm{PE}$ interpreted the data, wrote, and revised the manuscript. All authors read and approved the final manuscript.

\section{Acknowledgments}

This research was funded by the Central University of Ecuador, Project number 2, 2016, DI-072. We would like to thank Dr. Mauro Mendoza, Dr. Ramiro Montesdeoca, and all workers in the municipal slaughterhouse for providing all help for performing this study. Also, we thank Hannah Leigh Varnell for review the English of this document.

\section{Competing Interests}

The authors declare that they have no competing interests.

\section{Publisher's Note}

Veterinary World remains neutral with regard to jurisdictional claims in published institutional affiliation.

\section{References}

1. Food and Agriculture Organization of the United Nations. (2020) Livestock Production in Latin America and the Caribbean. Available from: http://www.fao.org/americas/prioridades/produccion-pecuaria/en. Retrieved on 13-04-2020.

2. Instituto Nacional de Estadística y Censos. (2016) Encuesta de Superficie y Producción Agropecuaria ContinuaESPAC. Available from: https://www.ecuadorencifras.gob. ec/encuesta-de-superficie-y-produccion-agropecuaria-continua-bbd. Retrieved on 23-04-2020.

3. Plaza, M.A. and Castillo, M.J. (2016) Estudios Industriales: Orientación Estratégica Para la Toma de DecisionesIndustria de Ganadería de Carne. Escuela Superior Politécnica del Litoral. ESPOL, Guayaquil, Ecuador.

4. Xing, T., Gao, F., Tume, R.K., Zhou, G. and Xu, X. (2019) Stress effects on meat quality: A mechanistic perspective. Compr. Rev. Food Sci. Food Saf., 18(2): 380-401.

5. McCleery, D.R., Stirling, J.M.E., McIvor, K. and Patterson, M.F. (2008) Effect of ante-and postmortem hide clipping on the microbiological quality and safety and ultimate $\mathrm{pH}$ value of beef carcasses in an EC-approved abattoir. J. Appl. Microbiol., 104(5): 1471-1479.

6. Węglarz, A. (2010) Meat quality defined based on $\mathrm{pH}$ and 
colour depending on cattle category and slaughter season. Czech J. Anim. Sci., 55(12): 548-556.

7. Węglarz, A. (2011) Effect of pre-slaughter housing of different cattle categories on beef quality. Anim. Sci. Pap. Rep., 29(1): 43-52.

8. Bautista, J.H., López, J.L.A., and Rincón, F.G.R. (2013) Pre-mortem handling effect on the meat quality. Nacameh, $7(2):$ 41-64.

9. Sheridan, J. (2007) Sources of Contamination During Slaughter and Measures for Control. J. Food Saf., 18(4): 321-339.

10. Delgado, H., Cedeño, C., de Ocaii, N.M. and Villoch, A. (2015) Hygienic quality of the meat obtained at slaughterhouses in Manabí- Ecuador. Rev. Salud Anim., 37(1): 1-9.

11. van Damme, I., Mattheus, W., Bertrand, S. and De Zutter, L. (2018) Quantification of hygiene indicators and Salmonella in the tonsils, oral cavity and rectal content samples of pigs during slaughter. Food Microbiol., 71(5): 120-128.

12. Camargo, A.C., Cossi, M.V.C., da Silva, W.P., Bersot, L.D.S., Landgraf, M., Baranyi, J., Franco, B.D.G. and Augusto, N.L. (2019) Microbiological testing for the proper assessment of the hygiene status of beef carcasses. Microorganisms, 7(3): 86.

13. Castillo, M.J. and Carpio, C.E. (2019) Demand for high-quality beef attributes in developing countries: The case of Ecuador. J. Agric. Appl. Econ., 51(4): 568-590.

14. Gómez, I.A.C. (2019) Evaluación de la Calidad de la Canal de Bovinos Faenados en la Empresa Pública Metropolitana de Rastro Quito (EMRAQ-EP) en Función del pH y contusiones, Bachelor of Veterinary Medicine, Universidad Central del Ecuador.

15. Gallardo, R.A.C. (2019) Evaluación del Bienestar Animal en el Ganado Porcino de la Empresa Pública Metropolitana de Rastro Quito, Bachelor of Veterinary Medicine, Universidad Central del Ecuador.

16. Parra, C.A.J. (2019) Evaluación del Bienestar Animal en el Sacrificio de Bovinos Post Capacitación en la Empresa Pública Metropolitana de Rastro Quito (EMRAQ-EP), Bachelor of Veterinary Medicine, Universidad Central del Ecuador.

17. Hidalgo, R.M.S. (2016) Evaluación de la Eficacia de la Insensibilización del Ganado Bovino en el Camal Metropolitano de Quito en Concordancia Con el Bienestar Animal, Bachelor of Veterinary Medicine, Universidad Central del Ecuador.

18. Grandin, T. (2019) Recommended Animal Handling Guidelines and Audit Guide: A Systematic Approach to Animal Welfare. North American Meat Institute, United States.

19. World Organization for Animal Health. (2020) Animal Welfare Standards. Available from: https://www.oie.int/en/ animal-welfare/an-international-network-of-expertise/\#c. Retrieved on 13-04-2020.

20. Hoffman, L.C. and Lühl, J. (2012) Causes of cattle bruising during handling and transport in Namibia. Meat Sci., 92(2): 115-124.

21. Instituto Ecuatoriano de Normalización. (2013) Carne y Productos Cárnicos-Medición de pH. No. INEN-ISO 2917: 2013. Instituto Ecuatoriano de Normalización, INEN, Ecuador.

22. Røssvoll, E., Hauge, S.J., Skjerve, E., Johannessen, G., Økland, M., Røtterud, O.J., Nesbakken, T. and Alvseike, O. (2017) Experimental evaluation of performance of sampling techniques for microbiological quantification on carcass surfaces. Food Prot. Trends, 37(6): 419-429.

23. Barros, M.A.F., Nero, L.A., Monteiro, A.A. and Beloti, V. (2007) Identification of main contamination points by hygiene indicator microorganisms in beef processing plants. Food Sci. Technol., 27(4): 856-862.

24. International Organization for Standardization. (2007) Microbiology of Food and Animal Feeding StuffsGeneral Requirements and Guidance for Microbiological
Examinations, ISO 7218: 2007. International Organization for Standardization, ISO, Ginebra, Switzerland.

25. Mainar-Jaime, R.C., Andrés, S., Vico, J.P., San Román, B., Garrido, V. and Grilló, M.J. (2013) Sensitivity of the ISO 6579: 2002/Amd 1: 2007 standard method for detection of Salmonella spp. on mesenteric lymph nodes from slaughter pigs. J. Clin. Microbiol., 51(1): 89-94.

26. Vinueza-Burgos, C., Cevallos, M., Ron-Garrido, L., Bertrand, S. and de Zutter, L. (2016) Prevalence and diversity of Salmonella serotypes in Ecuadorian broilers at slaughter age. PLoS One, 11(7): e0159567.

27. do Carmo, T.J., Peripolli, V., Costa J.B.G. Jr., Tanure, C.B., Fioravanti, M.C.S., Restle, J., Kindlein, L. and McManus, C. (2017) Carcass characteristics and meat evaluation of Nelore cattle subjected to different antioxidant treatments. Rev. Bras. Zootec., 46(2): 138-146.

28. Food and Agriculture Organization of the United Nations. (2020) Slaughter of Livestock. Available from: http://www. fao.org/3/x6909e/x6909e09.htm. Retrieved on 13-04-2020.

29. Zhang, Y.M., Hopkins, D.L., Zhao, X.X., van de Ven, R., Mao, Y.W., Zhu, L.X., Han, G.X. and Luo, X. (2018) Characterisation of $\mathrm{pH}$ decline and meat color development of beef carcasses during the early postmortem period in a Chinese beef cattle abattoir. J. Integr. Agric., 17(7): 1691-1695.

30. Calvin, P.T. (2013) Criterios Microbiológicos en Carnes, Propuesta Para el Control de la Higiene en Los Procesos, Food Security Specialist, Universidad Nacional de la Plata.

31. The Commission of the European Communities. (2007) Microbiological Criteria for Foodstuffs, Regulation (EC) No. 2073/2005. Official Journal of the European Union, Brussels, Belgium.

32. Boisbunon, A., Canu, S., Fourdrinier, D., Strawderman, W. and Wells, M.T. (2014) Akaike's information criterion, Cp and estimators of loss for elliptically symmetric distributions. Int. Stat. Rev., 82(3): 422-439.

33. Losada-Espinosa, N., Villarroel, M., María, G.A. and Miranda-de la Lama, G.C. (2018) Pre-slaughter cattle welfare indicators for use in commercial abattoirs with voluntary monitoring systems: A systematic review. Meat Sci., 138(4): 34-48

34. Miranda-de la Lama, G.C., Leyva, I.G., Barreras-Serrano,A., Pérez-Linares, C., Sánchez-López, E., María, G.A. and Figueroa-Saavedra, F. (2012) Assessment of cattle welfare at a commercial slaughter plant in the northwest of Mexico. Trop. Anim. Health Prod., 44(3): 497-504.

35. Strappini, A.C., Metz, J.H.M., Gallo, C.B. and Kemp, B. (2009) Origin and assessment of bruises in beef cattle at slaughter. Animal, 3(5): 728-736.

36. Faucitano, L., Chevillon, P. and Ellis, M. (2010) Effects of feed withdrawal prior to slaughter and nutrition on stomach weight, and carcass and meat quality in pigs. Livest. Sci., 127(2-3): 110-114.

37. Wang, S., Li, C., Xu, X. and Zhou, G. (2013) Effect of fasting on energy metabolism and tenderizing enzymes in chicken breast muscle early postmortem. Meat Sci., 93(4): 865-872.

38. Vogel, K.D., Claus, J.R., Grandin, T., Oetzel, G.R. and Schaefer, D.M. (2011) Effect of water and feed withdrawal and health status on blood and serum components, body weight loss, and meat and carcass characteristics of Holstein slaughter cows. J. Anim. Sci., 89(2): 538-548.

39. Muñoz, D., Strappini, A.C. and Gallo, C.B. (2012) Animal welfare indicators to detect problems in the cattle stunning box. Arch. Med. Vet., 44(3): 297-302.

40. Grandin, T. (2010) Auditing animal welfare at slaughter plants. Meat Sci., 86(1): 56-65.

41. Grandin, T. (2012) Auditing animal welfare and making practical improvements in beef-, pork- and sheep-slaughter plants. Anim. Welf., 21(1): 29-34.

42. Silva, F.F.P., Horvath, M.B., Silveira, J.G., Pieta, L. and Tondo, E.C. (2014) Occurrence of Salmonella spp. and generic Escherichia coli on beef carcasses sampled at a 
Brazilian slaughterhouse. Braz. J. Microbiol., 45(1): 17-24.

43. Alvseike, O., Røssvoll, E., Røtterud, O.J., Nesbakken, T., Skjerve, E., Prieto, M., Sandberg, M., Johannessen, G., Økland, M., Urdahl, A.M. and Hauge, S.J. (2019) Slaughter hygiene in European cattle and sheep abattoirs assessed by microbiological testing and hygiene performance rating. Food Control, 101(6): 233-240.

44. McEvoy, J.M., Doherty, A.M., Sheridan, J.J., ThomsonCarter, F.M., Garvey, P., McGuire, L., Blair, I.S. and McDowell, D.A. (2003) The prevalence and spread of Escherichia coli $\mathrm{O} 157$ : $\mathrm{H} 7$ at a commercial beef abattoir. J. Appl. Microbiol., 95(2): 256-266.

45. Bier, D., Kich, J.D., Duarte, S.C., Silva, M.R., Valsoni, L.M., Ramos, C.A.N., Rodrigues, D.P. and Araújo, F.R. (2018) Survey of Salmonella spp. in beef meat for export at slaughterhouses in Brazil. Pesqui. Vet. Bras., 38(11): 2037-2043.

46. Martinez-Chavez, L., Cabrera-Diaz, E., PerezMontano, J.A., Garay-Martinez, L.E., VarelaHernandez, J.J., Castillo, A., Lucia, L., Avila-Novoa, M.G., Cardona-Lopez, M.A., Gutierrez-Gonzalez, P. and Martinez-Gonzales, N.E. (2015) Quantitative distribution of Salmonella spp. and Escherichia coli on beef carcasses and raw beef at retail establishments. Int. J. Food Microbiol., 210(10): 149-155.
47. Bosilevac, J.M., Arthur, T.M., Bono, J.L., BrichtaHarhay, D.M., Kalchayanand, N., King, D.A., Shackelford, S.D., Wheeler, T.L. and Koohmaraie, M. (2009) Prevalence and enumeration of Escherichia coli O157: H7 and Salmonella in U.S. abattoirs that process fewer than 1, 000 head of cattle per day. J. Food. Prot., 72(6): 1272-1278.

48. Rahman, A., Khan, M., Qureshi, M., Ahmad, N., Shaheen, N., Din, S., Ali, T. and Pakistan, K.P. (2014) Washing of animal body coat effect on Salmonella load in post-slaughter carcasses. Sylwan, 159(3): 400-415.

49. Zweifel, C., Capek, M. and Stephan, R. (2014) Microbiological contamination of cattle carcasses at different stages of slaughter in two abattoirs. Meat Sci., 98(2): 198-202.

50. Adzitey, F. and Huda, N. (2012) Effects of post-slaughter carcass handling on meat quality. Pak. Vet. J., 32(2): 161-164.

51. Chulayo, A.Y. and Muchenje, V. (2013) The effects of pre-slaughter stress and season on the activity of plasma creatine kinase and mutton quality from different sheep breeds slaughtered at a smallholder abattoir. Asian-Australas $J$. Anim. Sci., 26(12): 1762-1772.

\section{$* * * * * * * *$}

